\title{
Československá diplomacie a příčiny rozpadu spojenectví s Izraelem
}

\section{Czechoslovak Diplomacy and the Causes of Breaking the Friendly Relations with Israel}

Eva Taterová / eva.taterova@mendelu.cz

Ústav teritoriálních studií Fakulta regionálního rozvoje a mezinárodních studií Mendelova univerzita $\vee$ Brně, CZ

\begin{abstract}
After World War II, the declaration of the independent Jewish state started to be discussed again by the international community. In these days, Czechoslovakia supported the Zionist movement/Israel in new-born organization of United Nations, and also provided an unofficial assistance to the Zionist movement through the arm supplies as well as military training to chosen Jewish volunteers. This cooperation was not immediately cancelled after the February coup in 1948 when the Communist Party of Czechoslovakia got a total dominance over politics of the country. In the long run, however, the communist rule in Czechoslovakia led to the growing tension in relations with Israel. Within next few year the mutual cooperation of both states was over and the mutual relations were close to the open hostility. One of the aims of this paper is to introduce the reasons that led to a shift of Czechoslovak attitude towards Israel, as well as the impact of these changes in the international context.
\end{abstract}

\section{Keywords}

Czechoslovakia; diplomacy; Israel; Cold War 


\section{Úvod}

Politické vztahy mezi Československem a sionistickým hnutím/Izraelem v průběhu 20. století zaznamenaly řadu proměn a zvratů. V období studené války lze tento stav považovat za unikátní především z toho důvodu, že zejména v počáteční časové etapě studenoválečného konfliktu neexistovalo mnoho jiných mimoevropských zemí, se kterými by Československo mělo natolik rozvinuté bilaterální vztahy. Za hlavní příčinu lze považovat ne zcela zanedbatelnou židovskou menšinu žijící na československém území stejně jako Židy československého původu nacházející se v mandátní Palestině/Izraeli. Etapy vzájemného přátelství a podpory mezi oběma entitami, které byly typické pro období první Československé republiky (1918-1938) a pro obnovený stát po druhé světové válce známý jako třetí Československá republika (1945-1948), byly na počátku 50. let vystřídány rostoucím napětím, místy až otevřeným nepřátelstvím.

Za určitý milník ve vývoji vzájemných vztahů lze považovat únor 1948, kdy Komunistická strana Československa (KSČ) definitivně převzala moc v zemi. Komunističtí představitelé v prvních poúnorových měsících přístup k sionistickému hnutí/Izraeli zásadněji nerevidovali, to se však mělo brzy změnit. Tento text si klade za cíl představit hlavní důvody této fundamentální změny přístupu Československa k židovskému státu. Na konkrétních přrikladech bude mít čtenář příležitost sledovat souvislost mezi konkrétními situacemi československo-izraelských vztahů a aktuálním mezinárodním děním v kontextu probíhající studené války.

Výzkum tématu je založen na studiu relevantních archivních pramenů, konkrétně se jedná o následující fondy: Archiv ministerstva zahraničních věcí ČR (AMZV) Teritoriální odbory-obyčejné (TO-O), Izrael, 1945-1959; AMZV TO-O, Izrael, 1960-1964, Teritoriální odbory-tajné (TO-T), Izrael, 1945-1955; AMZV TO-T, Izrael, 1955-1959; AMZV TO-T, Izrael, 1960-1964; AMZV TO-T, Izrael, 1965-1969; a Politické zprávy Zastupitelský úřad Tel Aviv 1950-196; Národní archiv ČR, Ústřední výbor Komunistické strany Československa 1945-1989, Kancelář 1. tajemníka ÚV KSČ Antonína Novotného - II. část (NA A ÚV KSČ 1945-1989, KTAN-II), k. 109 - Izrael. Výzkum je založen na tradičních metodách historické práce, zásadní pozornost je věnována zejména kritické analýze studovaných zdrojů vzhledem ke skutečnosti, že orgány komunistické správy často vědomě manipulovaly s prezentovanými fakty. Jednoznačně je to patrné především u pramenů týkajících se politických procesů první poloviny 50. let, často se ale podobné úmyslné manipulace objevují rovněž u hodnocení událostí souvisejících se zahraničně-politickými rozhodnutími Izraele nebo interpretace probíhající studené války.

\section{Etapa vzájemného přátelství}

Snaha projevit sounáležitost se zahraničně-politickými cíli Sovětského svazu byla patrná již v československé zahraniční politice od roku převzetí ministerstva 1945. Tyto trendy pochopitelně ještě posílily po únorovém převratu 1948 a po ovládnutí československé diplomacie komunisty v březnu téhož roku po nevyjasněném úmrtí dosavadního ministra 
Jana Masaryka ${ }^{1}$ a nástupu komunisty Vladimíra Clementise ${ }^{2}$. Úsilí o naprostou jednotu s postoji Sovětského svazu bylo upevňováno ve funkčních obdobích Clementisových následovníků Viliama Širokého ${ }^{3}$ a Václava Davida ${ }^{4}$, tedy po celé sledované období. ${ }^{5}$ Tento postoj byl opakovaně potvrzován také činy československých prezidentů působících ve sledovaném období. Jako příklad následování Sovětského svazu lze interpretovat jak pozitivní, tak i negativní přístup k Izraeli ve sledovaném období ze strany Československa. Již před vyhlášením Státu Izrael byl patrný kladný vztah Sovětského svazu k sionistickému hnutí, přičemž sovětská podpora existovala jak na oficiální úrovni, tak na neoficiální bázi. ${ }^{6}$

Vzhledem k stále napjatějším vztahům mezi supervelmocemi v období začínající studené války Sovětský svaz v některých případech preferoval nefigurovat v potencionálně citlivých politických záležitostech přímo, namísto toho využíval své satelitní státy jako prostředníky. Koncem 40. let 20. století bylo jako zprostředkovatel ve vztazích se sionistickým hnutím/Izraelem pravidelně využíváno právě Československo. Za hlavní prioritní oblast československé zahraniční politiky vůči Izraeli ve druhé polovině 40. let 20. století lze označit především snahu o šíření principo̊ komunismu. Československé stejně jako sovětské politické vedení opakovaně vyjadřovalo naděje, že by se Izrael mohl stát prvním socialistickým státem v regionu Blízkého východu nebo minimálně neutrální zemí v probíhajícím studenoválečném konfliktu. ${ }^{7}$

Jako konkrétní př́klad podpory sionistického hnutí před rokem 1948 lze uvést členství Československa ve Zvláštní komisi OSN pro Palestinu (UNSCOP), která byla založena v roce 1947 za účelem monitorování situace v tehdy ještě Velkou Británií ovládaném mandátním území. Vzhledem k tomu, že Sovětský svaz v této komisi svého zástupce neměl, je třeba roli Československa považovat za zásadní. V listopadu 1947 komise předložila známý Plán na rozděleni Palestiny, který lehce favorizoval požadavky sionistického hnutí oproti přáním arabských představitelů ${ }^{89} \mathrm{~V}$ květnu následujícího roku bylo Československo mezi prvními státy, které Stát Izrael po vyhlášení nezávislosti 14. května 1948

1 Jan Masaryk (1886-1948) byl československým diplomatem a politikem, synem prvního československého prezidenta Tomáše G. Masaryka. Byl mimo jiné známý svým vstřícným postojem k sionistickému hnutí.

2 Vladimír Clementis (1902-1952) byl slovenským politikem, publicistou a diplomatem, dlouholetým členem Komunistické strany Československa. Na počátku 50. let se stal obětí politických čistek, kdy byl popraven jako jeden z členů skupiny kolem Rudolfa Slánského.

3 Viliam Široký (1902-1971) byl slovenským politikem a dlouholetým členem Komunistické strany Československa. Po roce 1948 zastával řadu významných politických postů v československé vládě, v letech 1950-1953 působil na pozici ministra zahraničních věcí.

4 Václav David (1910-1996) byl českým politikem, dlouholetým členem Komunistické strany Československa, v letech 1953-1968 působil jako ministr zahraničních věcí.

5 Dejmek, Jindřich: Diplomacie Československa: Nástin dějin ministerstva zahraničních věcí a diplomacie (19181992). Praha 2012, s. 145-147.

6 Více viz Heller, Joseph: The United States, the Soviet Union and the Arab-Israeli Conflict, 1948-67: Superpower Rivalry. Manchester 2016.

7 Více viz Rucker, Laurent: Stalin, Izrael a Židé. Praha 2001.

8 V originále The United Nations Partition Plan for Palestine.

9 Zbořil, František: Československá a česká zahraniční politika: minulost a současnost. Praha 2010, s. 276. 
uznaly. V případě Československa a dalších zemí východního bloku se dokonce jednalo o uznání de iure (18. května 1948) - i v tomto ohledu československá diplomacie následovala postup Sovětského svazu, který stejný krok učinil o den dř́ve. ${ }^{10}$ Izrael své vyslanectví v Praze otevřel v červenci $1948^{11}$, kde se jako vyslanec akreditoval Ehud Avriel ${ }^{12}$. Otevření československého vyslanectví v Tel Avivu bylo schváleno v roce 1949, ale úřad začal fakticky fungovat až po př́jezdu československého vyslance Eduarda Goldstückera ${ }^{13}$ do Izraele v lednu $1950 .^{14}$

Významným př́kladem situace, kdy Sovětský svaz Československo pověřil důležitým úkolem ve vztahu k sionistickému hnutí/Izraeli, byly dodávky československých zbraní a dalšího vojenského materiálu ${ }^{15}$ v letech 1947-1951, které přispěly k vítězství Izraele v první arabsko-izraelské válce ${ }^{16}$. V první fázi byl tento proces realizován ministerstvem národní obrany, po únoru 1948 tyto dodávky probíhaly v koordinaci s ministerstvem zahraničních věcí. Finanční hodnota vzájemných smluv uzavřených v letech 1947 a 1948 dosáhla výše 144757 928,37 USD. ${ }^{17}$ Od počátku však bylo zřejmé, že Československo nechápalo dodávky zbraní Izraeli pouze jako formu přátelské pomoci, ale především jako obchodní transakci. Izraelský premiér David Ben-Gurion ${ }^{18} \mathrm{k}$ tomuto tématu ve svém projevu v izraelském parlamentu v květnu 1950 řekl: „[...] pochopitelně, že nikdo nedodává zbraně jako dar, a žádá penize a nikoliv rubly, nýbrž dolary a žádali milióny dolarü... ". 19

Stejnou optikou lze hodnotit poskytnutí vojenského výcviku židovským dobrovolníkům na území Československa v roce 1948. Jednalo se především o výcvik letců, který probíhal na letišti v Žatci a Českých Budějovicích. Vojenské letiště v Žatci zároveň sloužilo jako letecká základna pro dodávky materiálu leteckou cestou, i když s nutným mezi-

10 International Recognition of Israel. (C) 1998-2018, http://www.jewishvirtuallibrary.org/jsource/Peace/recogIsrael.html, citováno 11. 3. 2018.

11 Zídek, Petr - Sieber, Karel: Československo a Blizký východ v letech 1948-1989. Praha 2009, s. 128.

12 Ehud Avriel (1917-1980), původním jménem Ehud Überall, byl izraelským politikem a diplomatem původně pocházejícím z Rakouska-Uherska, na území jehož následnických států se posléze politicky angažoval. Mimo jiné se významně zasadil o zprostředkování dohody o prodeji československých zbraní Izraeli.

13 Eduard Goldstücker (1913-2000) byl československým komunistickým politikem, diplomatem, profesorem germanistiky a překladatelem. Na počátku 50. let se stal jednou z obětí Slánského procesu, v roce 1955 byl rehabilitován a zahájil akademickou kariéru na katedře germanistiky na Karlově univerzitě. Po intervenci vojsk Varšavské smlouvy do Československa v roce 1968 emigroval do Velké Británie.

14 Goldstücker, Eduard: Vzpominky. 1945-1968. Praha 2005, s. 40-42.

15 Fakticky se jednalo o pěchotní pušky, kulomety, pistole, minomety, houfnice, granáty, letouny Spitfire, munici a další vojenský materiál.

16 První arabsko-izraelská válka (1948-1949), nazývaná též válka za nezávislost nebo al nakba (katastrofa), byla vojenským konfliktem mezi nově vzniklým státem Izrael a okolními sousedními státy. Izrael vítězstvím v této válce potvrdil svou existenci a územní integritu.

17 Dufek, Jiří - Kaplan, Karel - Šlosar, Vladimír: Československo a Izrael v letech 1947-1953. Studie. Praha 1993, s. 51.

18 David Ben-Gurion (1886-1973) byl dlouholetým vůdcem sionistického hnutí a izraelským politikem, který zastával řadu nejvyšších politických funkcí ve vedení země. Byl dlouholetým izraelským premiérem a předsedou izraelské Strany práce Mapaj.

19 Návrh na úpravu vzájemných vztahů mezi ČSR a Izraelem, čj. 414306, 5. 7. 1954, s. 17. AMZV Praha, TO-T, Izrael, 1945-1954. 
přistáním na Korsice. ${ }^{20}$ Odhady hovoří o tom, že vojenským výcvikem v Československu prošlo více než 200 příslušníků Hagany ${ }^{21}$, celkově zde různé formy výcviku absolvovalo více než 1200 osob z Československa a dalších zemí. ${ }^{22}$

V této etapě Československo stejně jako Sovětský svaz a další státy východního bloku velmi vstřícně přistupovalo k povolování migrace československých Židů za účelem odchodu do Izraele. Podle zprávy československého ministerstva zahraničních věcí z 25. května 1954 reflektující emigraci Židů z Československa do Izraele v letech 1948-1954 mělo v období následujícím po vyhlášení nezávislého židovského státu 14. května 1948 do května 1949 opustit Československo 18000 osob židovského původu. Zpráva se odkazuje na izraelské záznamy o počtech nově příchozích, ale zůstává otázkou, nakolik se jedná o ověřené číslo, což připustil i samotný autor zprávy referent Alois Bartůšek. ${ }^{23}$

Tehdejší československý ministr zahraničních věcí Vladimir Clementis sice plánoval téma emigrace československých Židů projednat na zasedání vlády, ale návrh byl 21. prosince 1948 z jednání stažen a posléze se již o této otázce znovu nejednalo. Emigrace se tak prováděla na základě kladného doporučení porady ministrů z 1. prosince 1948 . Na bázi výsledků této porady československé ministerstvo zahraničních věcí vypracovalo návrh, ve kterém je vyjádřen souhlas s emigrací 20000 Židů do Izraele. Emigrace probíhala jak formou individuálních žádostí, tak hromadných transportů organizovaných československým ministerstvem vnitra, které tuto akci připravilo ve spolupráci s ministerstvem sociální péče. ${ }^{24}$

\section{Období politických procesů 50. let v Československu}

Počáteční přátelství mezi Izraelem a státy východního bloku, včetně Československa, brzy vystřídaly rozpory a stále rostoucí vzájemné odcizování, které vyvrcholilo v době politických procesů v první polovině 50. let 20. století. Případem, který vzbudil velkou pozornost celého mezinárodního společenství, byla kauza Rudolfa Slánského ${ }^{25}$ a jeho spolupracovníků, která se odehrála v Československu v letech 1951 a 1952. Podle obžaloby měla skupina spiklenců kolem Slánského usilovat o vytržení Československa ze spojenectví se Sovětským svazem a sabotovat politiku socialistické výstavby. Slánský byl

20 Avriel, Ehud: Open the Gates! The Dramatic Personal Story of ,Illegal Immigration“ to Israel. New York City 1975, s. 345 .

21 Hagana je termín, kterým se označuje židovská domobrana. Byla založená roku 1920, stala se předchůdkyní izraelské armády.

22 Dufek, J. - Kaplan, K. - Šlosar, V.: Československo a Izrael, s. 61-65; Zídek, P. - Sieber, K.: Československo a Blizký východ, s. 129.

23 AMZV Praha, TO-T, Izrael, 1945-1954. Emigrace do Izraele od roku 1948, čj. 419481, 25. 5. 1954, s. 1-3.

24 Vystěhovalectví z ČSR do Palestiny, čj. 244746, 8. 12. 1948, s. 1-3. AMZV Praha, TO-O, Izrael, 1945-1959, kart. 9.

25 Rudolf Slánský (1901-1952) byl československým komunistickým politikem, vrchol jeho kariéry představovalo období let 1945-1951, kdy vykonával funkci Generálního tajemníka Komunistické strany Československa. Na počátku 50. let se stal obětí politických čistek, jeho proces byl zamýšlen a prezentován jako exemplární příklad pro další vysoce postavené komunistické politiky v zemích východního bloku. 
osobně obviněn z tzv. trockisticko-titoisticko-sionistické činnosti. Všichni obžalovaní se nakonec pod nátlakem StB přiznali ke špionáži, velezradě, sabotáži a prozrazení vojenského tajemství. Jedenáct z obžalovaných včetně Slánského bylo odsouzeno k smrti, tři obžalovaní obdrželi trest odnětí svobody na doživotí. ${ }^{26}$

Personální čistky, které přišly v období politických procesů iniciovaných Moskvou, měly na vztah Československa k Izraeli velmi negativní dopady. Představitelé židovského státu odsuzovali jak vykonstruovanost procesů, tak i výrazný prvek antisemitismu, který se v jejich průběhu objevoval. Situaci dále komplikoval fakt, že mezi v Československu v roce 1951 zatčené a o dva roky později odsouzené patřili kromě řady Čechoslováků židovského původu i dva izraelští občané - Mordechaj Oren ${ }^{27}$ a Šimon Orenstein ${ }^{28}$, kteří byli obviněni ze špionážních aktivit a snah poškodit a rozvrátit československý stát. Ačkoli k zatčení izraelských státních př́íslušníků došlo i v několika jiných případech, nikdy tyto kauzy nevzbudily velkou mezinárodní pozornost. Vzhledem k tomu, že jeden ze zatčených, Mordechaj Oren, byl v době svého zatčení poslancem levicově orientované strany Mapam, jeho zatčení v Československu vedlo k rozkolu v izraelské levici, která se musela vypořádat s tím, jaký bude nadále její vztah s lidově demokratickými státy. ${ }^{29}$

Vnímání situace v Československu velmi dobře ilustruje projev tehdejšího izraelského ministra zahraničí Moše Šareta pronesený dne 28. listopadu 1952 na setkání zástupců strany Mapaj v Tel Avivu: „Celý svět stoji v těchto dnech přimražen a v úžasu hledi na kejkliřrskou vidinu po době procesu, který je uváděn tentokrát na jevišti československého soudu. Vi̊dcové strany a kormidelníci režimu, kteři teprve včera a predevčírem stáli v čele tábora svých druhů, panovali nad politikou země a ovládali jeji osud, jsou dnes vystavováni na ukázku jako skupina spiklenců a zrádců, podvodniků a sabotérů. Většina obžalovaných jsou židé a prokuratura pečovala o to, aby zdi̊raznila jejich piovod a jemu připsala jejich zdánlivé zločiny [...] Ulovila do své sitě izraelské občany a pričítá jim naprosto bezpodstatné viny podrýváni a sabotáže. "30

Diplomatickou roztržku mezi oběma zeměmi potvrzuje i fakt, že v přímé návaznosti na Orenův a Orensteinův případ byl izraelský chargé d'affaires v Praze Arie L. Kubovy ${ }^{31}$

26 Více viz Ströbinger, Rudolf: Vražda generálního tajemnika: posledni Stalinův exemplárni proces, soud s Rudolfem Slánským. Brno 1991.

27 Mordechaj Oren (1905-1985) byl levicovým izraelským politikem za stranu Mapam a členem kibucnického hnutí. V prosinci 1951 byl zatčen v Československu, posléze byl nucen svědčit v procesu proti Rudolfu Slánskému. V roce 1953 byl odsouzen k patnáctiletému trestu vězení a peněžitému trestu za podporu západního imperialismu a snahu o rozvrácení komunistického režimu v Československu. Na svobodu byl propuštěn v květnu 1956, v 60. letech byl československým Nejvyšším soudem plně očištěn a rehabilitován.

28 Šimon Orenstein (1904-1980) krátce pracoval pro ekonomickou sekci izraelského vyslanectví v Praze, posléze se živil jako obchodník zprostředkovávající ekonomickou výměnu mezi východním a západním blokem. V prosinci 1951 byl zatčen při pokusu o překročení československo-rakouských hranic, posléze jej StB donutila svědčit proti skupině kolem Rudolfa Slánského. V roce 1953 byl odsouzen na doživotí, v říjnu 1956 však obdržel amnestii od prezidenta Zápotockého. V 60. letech byl jeho případ československými soudy znovu otevřen a Oren se dočkal rehabilitace.

29 Záznam rozhovoru s Jakobem Majusem, dne 14. XII. 1952, čj. sine, s. 2. AMVZ Praha, TO-O, Izrael, $1945-1954$.

30 Mimoŕádná politická zpráva č. 19 za prosinec ze dne 18. 12. 1952, čj. sine, 18. 12. 1952, s. 1. AMZV Praha, TOO, Izrael, 1945-1959, kart. 2.

31 Arie Leon Kubovy (1896-1966) byl izraelským právníkem, diplomatem a jedním z vůdců sionistického hnutí. Kromě mise v Československu sloužil jako ambasador v Polsku a v Latinské Americe. 
v prosinci 1952 označen československým ministerstvem zahraničních věcí jako persona non grata a byl následně nucen Československo opustit. Jako důvod československé úřady uvedly nepřípustné vměšování se izraelské ambasády pod vedením Kubovyho do československých vnitrostátních záležitostí. ${ }^{32}$ Tato eskalace událostí zřetelně demonstrovala vážný diplomatický rozkol mezi Československem a Izraelem, přičemž ze spisů současně vyplývá, že československá diplomacie neměla vážnější obavy z dopadů této události na vzájemné vztahy: „Ak by sa izraelská vláda uchýlila $k$ nejakým odvetným opatreniam alebo nového vyslanca do ČSR nevyslala, nehrozila by z toho našim záujmom nijaká ujma. My máme v Izraeli len chargé d'affaires a menovanie vyslanca zatial' neplánujeme. Bolo by teda pre nás vcelku prijatel'né, keby naše diplomatické vztahy $v$ dlhšej perspektive zostaly na úrovni chargé d'affaires. "33

Obětí politických procesů se stal také první československý vyslanec v Izraeli Eduard Goldstücker, který byl údajně mimo jiné kvưli svému židovskému původu po odvolání z Tel Avivu v roce 1951 několik let vězněn. ${ }^{34}$ Jako oficiální důvod jeho zatčení a odsouzení však československá prokuratura uváděla skutečnost, že Goldstücker měl tvořit spojku mezi Slánského spikleneckým centrem v Praze a Koni Zilliacem, členem britské špionážní služby. ${ }^{35}$ Jak dokládají dostupné tiskové zprávy, Goldstückerův osud byl nejen v Izraeli pozorně sledován.

Situaci ještě více vyostřily události přelomu let 1952 a 1953 poté, kdy radikální sionistická skupina Království izraelskés6 provedla několik útoků na budovy československého a sovětského vyslanectví v Tel Avivu. Vůdce skupiny Jaakov Cheruti později u soudu vysvětloval motivy útoků na ambasády Československa a SSSR jako formu protestu proti útlaku Židů v zemích východního bloku v okamžiku, kdy při ochraně jejich práv selhala izraelská vláda. ${ }^{37}$ Nejvážnější následky měl bombový útok na sovětskou ambasádu v Tel Avivu 9. února 1953, při kterém došlo ke zničení části budovy velvyslanectví a současně ke zranění tří lidí, kteří v budově pobývali. ${ }^{38}$ Zástupci Sovětského svazu od počátku vyšetřování nahlíželi na práci izraelské policie s krajním podezřením, protože se domnívali, že vyšetřování útoku není prováděno s dostatečnou vážností. Tato situace eskalovala v hlubší diplomatickou roztržku, během níž na několik měsíců došlo k oficiálnímu přerušení izraelsko-sovětských diplomatických vztahů. ${ }^{39}$

32 Návrh na úpravu vzájemných vztahů mezi ČSR a Izraelem, čj. 414306, 5. 7. 1954, s. 20. AMZV Praha, TO-T, Izrael, 1945-1954..

33 Výpoved’ M. Orena o izr. Vyslancovi Kubovom, čj. 139048, 21. 11. 1952, s. 1. AMZV Praha, TO-O, Izrael, 1945-1959, kart. 2.

34 Goldstücker, E.: Vzpominky, s. 58-62.

35 Návrh na úpravu vzájemných vztahů mezi ČSR a Izraelem, čj. 414306, 5. 7. 1954, s. 18. AMZV Praha, TO-T, Izrael, 1945-1954.

36 Království izraelské bylo pravicovou radikální sionistickou skupinou, která působila v letech 1951-1953. Zaměřovala se na kritiku stávajícího společenského uspořádání v Izraeli stejně jako na otevřené protesty vůči antisemitismu v komunistických zemích.

37 Pedahzur, Ami - Perlinger, Arie: Jewish Terrorism in Israel. New York City 2013, s. 34.

38 Nota sovětské vlády o přerušeni diplomatických styků s izraelskou vládou, čj. sine, únor 1953. AMZV Praha, TO-O, Izrael, 1945-1954, kart. 1.

39 Návrh na úpravu vzájemných vztahů mezi ČSR a Izraelem, čj. 414306, 5. 7. 1954, s. 13. AMZV Praha, TO-T, Izrael, 1945-1954. 
Zcela vážně možnost přerušit diplomatické vztahy s Izraelem zvažovalo rovněž Československo, ačkoliv útoky na budovu československé ambasády v Tel Avivu způsobily jen menší materiální škody. Českoslovenští představitelé se nakonec po poradě se sovětskými zástupci rozhodli diplomatické vztahy s Izraelem zachovat. ${ }^{40}$ Hlavní důvody pro toto rozhodnutí však nelze hledat ani tak v naději na zlepšení vzájemných styků v budoucnosti, ale spíše v jiných příčinách. Na základě dostupných informací lze usuzovat, že Československo se v této době již téměř vzdalo myšlenky, že by se Izrael v dohledné době mohl stát socialistickým státem, a to vzhledem k př́ístupu vládnoucí garnitury k této otázce. Důležitější prioritou československé zahraniční politiky v tomto období bylo zachovat si funkční zastupitelský úřad v oblasti Blízkého východu tak, aby bylo možné efektivně monitorovat dění v regionu.

\section{Vývoj do šestidenní války}

Ke krátkému období oteplení československo-izraelských vztahů došlo v druhé polovině 50. let po propuštění obou v Československu vězněných Izraelců Š. Orensteina (1954) a M. Orena (1956) a po celkové revizi období stalinismu v návaznosti na politické změny v Sovětském svazu po smrti Stalina v roce $1953 .{ }^{41}$ Především Izrael vkládal do možnosti vylepšení československo-izraelských vztahů velké naděje, což se mimo jiné projevilo v personální obměně na izraelském vyslanectví v Praze - jako nový vyslanec se akreditoval Šlomo Kaddar ${ }^{42}$ s vizí, že se díky jeho jmenování a jmenování některých nových nižších úředníků podaří odstranit případnou osobní averzi, která mezi izraelskými a československými zástupci mohla existovat. Tyto naděje se nakonec nenaplnily, př́íčny je nutné hledat hlavně v širších souvislostech probíhající studené války a regionálním dění na Blízkém východě.

Do roku 1956 se datují události Suezské krize ${ }^{43}$, které kromě eskalace nepřátelství ve vztazích mezi Izraelem a Egyptem měly významné dopady i na mezinárodní politiku v širším měřítku, především pak na vztahy mezi supervelmocemi SSSR a USA. ${ }^{44}$ Československo po sovětském vzoru okamžitě jednání Izraele a jeho evropských spojenců Francie a Velké Británie odsoudilo, přičemž vzájemné vztahy se propadly na nezbytně nutnou formální úroveň. V této době dokonce došlo k naprostému zastavení židovské migrace

40 Tamtéž, s. 22-23.

41 Za zlomový okamžik je považován projev Nikity Chruščova na XX. sjezdu KSSS v únoru 1956, kdy došlo k odsouzení kultu osobnosti a diktátorství Chruščovova předchůdce Stalina.

42 Šlomo Kaddar (1913-1987), původním jménem Friedrich Kessler, byl izraelský diplomat, příslušník Hagany a člen kibucnického hnutí.

43 Suezská krize (1956) byl vojenský střet mezi Egyptem na jedné straně a Izraelem, Francií a Velkou Britániî na straně druhé. Vojenské vítězství protivníků Egypta ve svých důsledcích nevedlo k výhře na poli diplomatickém. Více viz např. Varble, Derek: The Suez Crisis 1956. London 2014.

44 Více viz například Morris, Benny: Righteous Victims: A History of the Zionist-Arab Conflict, 1881-1998. New York City 2011; McNamara, Robert: Britain, Nasser and the Balance of Power in the Middle East, 1952-1977: From The Eygptian Revolution to the Six Day War. London 2004; Johnson, Paul: Dějiny židouského národa. Praha 1995. 
z Československa do Izraele, což bylo ve sledovaném období zcela poprvé. ${ }^{45}$ Do období druhé poloviny 50. let rovněž spadá prohlubování československých vazeb na vybrané arabské státy - jednalo se především o Irák, Jemen, Sýrii a částečně i Egypt - které jevily ochotu alespoň částečně aplikovat na svém území principy socialismu. Prvním státem, se kterým byla na základě tohoto předpokladu v roce 1955 uzavřena smlouva o dodávkách zbraní a dalšího vojenského materiálu, se stal Egypt, později byly obdobné kontrakty uzavřeny i s dalšími zeměmi. ${ }^{46}$ Postupem času se dokonce navázání a udržení dobrých vztahů se spřátelenými státy tzv. třetího světa stalo jednou z priorit československé zahraniční politiky a to pochopitelně nejen v regionu Blízkého východu. ${ }^{47}$

Vztahy mezi Československem a Izraelem zůstaly až do konce 50. let velmi napjaté, typickým rysem byla atmosféra konstantního podezřívání se z nepřátelských úmyslů a obecně snahy protistranu poškodit. Československo např́klad velmi negativně vnímalo rozmístění policejních hlídek před budovu svého vyslanectví v Tel Avivu v době událostí Suezské krize a několik týdnů po jejím skončení. Kategoricky přitom odmítalo interpretaci izraelského ministerstva zahraničních věcí, že se jedná o ochranné opatření, protože izraelská veřejnost měla být vưči Československu kvůli jeho otevřené podpoře arabských států nepř́íznivě naladěná. ${ }^{4} \mathrm{Na}$ jaře roku 1957 pak došlo k další diplomatické roztržce, která vedla k vzájemnému vyhoštění diplomatů. Nejprve byl 29. března 1957 označen jako persona non grata sekretářr-archivář izraelského vyslanectví v Praze Moše Schatz kvůli údajné špionáži. ${ }^{49}$ Izraelské ministerstvo zahraničních věcí v reakci na tento případ 2. dubna 1957 předalo československému chargé d'affaires Jobánkovi diplomatickou nótu, ve které jej informovalo o prohlášení Jaromíra Vašíčka, atašé zastupitelského úřadu ČSR v Tel Avivu, rovněž za persona non grata. Důvodem jako v případě Schatze měla být údajná špionáž. ${ }^{50}$ Objevilo se několik návrhů, jak by na tuto situaci měla československá diplomacie reagovat. I když se uvažovalo o odvetném vypovězení dalšího diplomatického pracovníka izraelského vyslanectví v Praze, nakonec převážila mírnější reakce v podobě oficiálního protestu. Tento postup byl zvolen především s ohledem na postoj Sovětského svazu, který si nepřál další eskalaci napětí v československo-izraelských vztazích. ${ }^{51}$

Po výměně vedoucího izraelského zastupitelského úřadu v Praze v létě 1957 chargé d'affaires Šlomo Kaddara nahradil Šmuel Bendor ${ }^{52}$. Současně se rozhodl Izrael udělat vưči Československu vstřícný krok a přistoupil k jednostrannému navýšení úrovně

45 Návrhy izr. vyslance na obch. a kult. styky, čj. 0011, 13. 1. 1958, s. 5. AMVZ Praha, TO-T, Izrael, 1955-1959, kart. 1.

46 Politická zpráva č. 2, čj. 023366, 26. 3. 1963, s. 1-2. NA Praha, A ÚV KSČ 1945-1989, KTAN-II, kart. 144.

47 Zbořil, F.: Československá a česká zahranični politika, s. 254-260.

48 Policejní opatření vưči ZÚ Tel Aviv, čj. 075, 28. 3. 1957, s. 1. AMZV Praha, TO-T, Izrael 1955-1959, kart. 1.

49 Protistátni činnost diplomatického pracovnika izraelského vyslanectvi v Praze, čj. 013040, 29. 3. 1957, s. 1. AMZV Praha, TO-T, Izrael 1955-1959, kart. 1.

50 Vypovězeni s. Vašička z Tel Avivu - protestni nóta, čj. 013365, 9. 4. 1957, s. 1. AMZV Praha, TO-T, Izrael 1955-1959, kart. 1.

51 Tamtéž.

52 Šmuel Bendor (1934-2007) působil jako izraelský diplomat v Československu, Rumunsku a dalších zemích. 
diplomatického zastoupení - Bendor přišel do Československa v pozici vyslance..$^{53}$ Československo se však k obdobnému kroku nepřiklonilo a po zbytek svého diplomatického působení v Izraeli, tj. do června 1967, bylo vždy reprezentováno jen na úrovni chargé d'affaires, i když diskuze o možném navýšení diplomatické úrovně proběhly ještě několikrát, většinou v případě, kdy došlo k personální výměně vedoucího československého zastupitelského úřadu v Tel Avivu jako například v roce 1959, kdy Zdeňka Jobánka vystřídal Miloslav Hrůza. V tomto konkrétním případě se uvažovalo, že by Hrůza mohl přijít do Izraele v hodnosti rady a poté být případně povýšen na vyslance. $\mathrm{K}$ realizaci tohoto plánu nakonec nedošlo. ${ }^{54}$

Izraelský vyslanec v Praze Šmuel Bendor během svého působení v Československu předložil návrh na zlepšení československo-izraelských ekonomických a kulturních vztahů, přičemž přednesl do té doby bezprecedentní návrh oboustranně odepsat nedořešené vzájemné pohledávky vzniklé před rokem 1950. Československé ministerstvo zahraničních věcí však všechny tyto podněty odmítlo. Jako hlavní důvody interní dokumenty uvádějí nedůvěru v dobré úmysly Izraele a především obavu z narušení vztahů mezi Československem a arabskými zeměmi, které by si jmenování československého vyslance pro Izrael mohly vyložit jako indicii podpory Československa židovskému státu. ${ }^{55} \mathrm{Je}$ možné konstatovat, že na přelomu 50. a 60. let bylo udržení pokud možno fungujících diplomatických československo-izraelských vztahů větší prioritou pro Izrael než pro Československo především s ohledem na československé Židy a v neposlední řadě na průběh arabsko-izraelského konfliktu.

Novým motivem, který ve druhé polovině 60. let poznamenal československo-izraelské vztahy, byla narůstající spolupráce mezi Izraelem a západním Německem. Přístup sionistického hnutí/Izraele po druhé světové válce $\mathrm{k}$ oběma německým státům byl výrazně zatížen událostmi holocaustu. Západní Německo pod vedením kancléře Konrada Adenauera ${ }^{56}$ si kladlo za cíl přijmout zodpovědnost za zločiny, které byly na Židech nacistickým Německem v minulosti spáchány, a alespoň částečně je odčinit prostřednictvím finančních reparací a politické podpory Izraeli. Izraelská společnost otázku možného vypořádání se s minulostí a navázání diplomatických vztahů se západním Německem vnímala velmi citlivě, v řadě případo̊ dokonce kriticky. Přesto se roku 1952 podařilo uzavřít tzv. Lucemburské dohody o finančních reparacích, které západní Německo přislíbilo Izraeli uhradit. ${ }^{57} \mathrm{~V}$ roce 1965 pak došlo k oficiálnímu navázání diplomatických vztahů mezi oběma státy, kterému předcházelo postupné sbližování se. Československo tento vývoj sledovalo velmi kriticky, a to ze dvou hlavních důvodů. Prvním důvodem byly pochopitelně vazby na východní Německo, které uznávalo jako výhradního představitele německého národa. Druhým důvodem pak byla v některých případech více a v někte-

53 AMZV Praha, TO-T, Izrael, 1945-1954. Telegram z Paříže, čj. 124770, 19. 7. 1957.

54 Dopis ministra zahraničních věcí V. Davida prezidentu A. Novotnému ohledně možnosti jmenovat vyslance v Izraeli, čj. 0063, 24. 3. 1960, s. 2-3. NA Praha, A ÚV KSČ 1945-1989, KTAN-II, kart. 109.

55 Informace o čs. - izraelských vztazich, čj. sine, 17. 3. 1958, s. 5. AMZV Praha, TO-O, Izrael, 1945-1959, kart. 6.

56 Konrad Adenauer (1876-1967) byl německý politik a první poválečný kancléř západního Německa.

57 Gilbert, Martin: Izrael: dějiny. Praha 2002, s. 283-287. 
rých případech méně opodstatněná kritika západního Německa za to, že na vysokých politických a vojenských postech působí lidé s nacistickou minulostí. ${ }^{58}$

Tento československý postoj se zřetelně projevil na počátku 60. let, kdy se po zajetí nacistického zločince Adolfa Eichmanna ${ }^{59}$ izraelskou tajnou službou Mosad v Argentině v roce 1961 uskutečnil v Jeruzalémě soud, který téma událostí druhé světové války a částečně i následného politického vývoje opětovně otevřel. ${ }^{60}$ Československo bylo v soudním procesu s Eichmannem zainteresováno dvojím zpơsobem. Zaprvé se část Eichmannových zločinů odehrála na československém území či postihla československé občany. Československo si v době bezprostředně po Eichmannově zatčení, tj. v létě 1960, dokonce pohrávalo s myšlenkou požádat Izrael o vydání Eichmanna do Prahy, kde by byl rovněž postaven před soud. Nakonec však tato žádost nebyla oficiálně vznesena z důvodu nízké pravděpodobnosti dosažení požadovaného výsledku. ${ }^{61}$ Druhým důvodem, proč bylo Československo v Eichmannově kauze zainteresováno, byla žádost izraelské strany o poskytnutí důkazních materiálů o Eichmannových zločinech na československém území, kterou vznesl prostřednictvím diplomatické nóty chargé d'affaires Elijahu Livneh 25. srpna 1960. Československo tak bylo postaveno před obtížné dilema, kdy na jednu stranu nechtělo být vnímáno jako stát, který důkazní materiály nevydá a tím pádem by mohl být obviněn z nepřímé podpory nacismu. Současně se však Československo bránilo navázání jakékoliv formy oficiální spolupráce s Izraelem. Nakonec převážilo kompromisní řešení, kdy důkazy o Eichmannových zločinech poskytnul na konferenci konané 3. listopadu 1960 Svaz protifašistických bojovníků, který oficiálně nebyl státní institucí. Československo se snažilo o co nejopatrnější postoj z obav, aby nedošlo k narušení jeho vztahů s arabskými státy a Argentinou. ${ }^{62}$

Přístup Československa k Eichmannově soudnímu procesu ukazuje, že i v 60. letech byly československo-izraelské vztahy stále velmi napjaté. Tento fakt potvrzuje Koncepce československo-izraelských vztahů schválená kolegiem ministerstva zahraničních věcí dne 19. května 1961. Jako základní podmínku pro možnou normalizaci vzájemných vztahů československá diplomacie vnímala nutnost zásadní změny směřování izraelské zahraniční politiky, tedy odklon od západních spojenců, což však nebylo chápáno jako příliš reálná možnost. ${ }^{63}$ Diplomatické zastoupení mělo být ponecháno na úrovni chargé d'affaires,

58 Proces s Adolfem Eichmannem, čj. 030428, 11. 9. 1961, s. 17. AMZV Praha, TO-T, Izrael, 1960-1964, kart. 2.

59 Adolf Eichmann (1906-1962) byl německý nacistický funkcionář a válečný zločinec zodpovědný za koncept tzv. finálního řešení židovské otázky. Po skončení druhé světové války uprchl do Argentiny, kde až do svého dopadení žil pod falešným jménem Ricardo Klement.

60 Více viz Arendtová, Hannah: Eichmann v Jeruzalémě: Zpráva o banalitě zla. Praha 1995; Ceasarani, David: Eichmann: His Life and Crimes. New York City 2005; Lipstadt, Deborah E.: The Eichmann Trial. New York City 2001.

61 Záznam o důležitějšich rozhovorech, pracovniků ZÚ Tel Aviv, čj. 058, 10. 3. 1961, s. 13. AMZV Praha, TO-T, Izrael, 1960-1964, kart. 1.

62 Záznam z porady o Eichmannovi, čj. 027198, 5. 7. 1960, s. 2. AMZV Praha, TO-T, Izrael, 1960-1964, kart. 2.

63 Koncepce československo-izraelských vztahů, čj. 0245595, 13. 5. 1961, s. 24. AMZV Praha, TO-T, Izrael, 19601964, kart. 1. 
pouze v případě pozitivního vývoje arabsko-izraelského konfliktu by mohlo být uváženo navýšení diplomatického zastoupení na úroveň vyslance. ${ }^{64}$

Zcela zřetelně se tedy projevila prioritní orientace Československa na arabské země, která byla v 60. letech potvrzena mimo jiné uzavřením série smluv s jednotlivými státy o ekonomické spolupráci, dodávkách zbraní a vojenského materiálu, spoluprací v kulturní oblasti atd. Uzavřené dohody se týkaly zejména Egypta, Jemenu a Sýrie, ale postupem času Československo věnovalo stále více pozornosti palestinskému hnutí reprezentovanému OOP ${ }^{65}$ Izrael za tento přístup Československo konstantně kritizoval a nepřímo jej obviňoval z přípravy vojenského útoku proti Izraeli. ${ }^{66}$ Oproti tomu Izrael byl Československem označován za agenta kapitalistických a koloniálních velmocí, především s ohledem na svou roli v nově nezávislých zemích Afriky a jihovýchodní Asie. Izrael představoval v těchto zemích pro Československo a další socialistické země do určité míry konkurenci především s ohledem na politický vliv, kdy de facto ohrožoval rozšíření sféry vlivu východního bloku v těchto světových regionech. ${ }^{67}$

\section{Přerušení diplomatických vztahů mezi ČSSR a Izraelem}

Definitivní bod zlomu ve vzájemných československo-izraelských vztazích znamenaly události šestidenní války, která se odehrála 5.-10. června 1967. Již nějakou dobu před zahájením vojenských operací byl na Blízkém východě patrný vzestup napětí mezi Izraelem a arabskými státy. Izraelská vláda vedená premiérem Levym Eškolem ${ }^{68}$ vnímala jako zásadní nebezpečí rostoucí militarizaci sousedních arabských států a prohlubování vazeb mezi nimi, což chápala jako přípravu na válku s cílem zničit židovský stát. Dodnes zůstává poměrně kontroverzní otázkou, do jaké míry bylo toto podezření opodstatněné, ale faktem zůstává, že Izrael se v této věci nakonec rozhodl nečekat na výsledky diplomatických vyjednávání a k 5. červnu 1967 zahájil vojenskou operaci Moked, která si v první fázi kladla za cíl zasáhnout významné strategické a vojenské cíle v Egyptě, Jordánsku a Sýrii. ${ }^{69}$

Výsledky šestidenní války lze hodnotit jako jednoznačné vojenské vítězství Izraele, který nejenže uhájil svou existenci a demonstroval svou sílu, ale současně dosáhnul znovuotevření Tiranské úžiny a znatelně rozšíríl své území o východní Jeruzalém, Západní břeh, Golanské výšiny, pásmo Gazy a Sinajský poloostrov. Takto rychlé a přesvědčivé vítězství významným způsobem zvýšilo prestiž Izraele a sebevědomí židovského národa. Na druhou stranu však měla šestidenní válka řadu dopadů na další vývoj v regionu, ně-

64 Perspektivy stykư mezi ČSSR a Izraelem, čj. 027735, 1. 7. 1961, s. 2. AMZV Praha, TO-T, Izrael, 1960-1964, kart. 1.

65 Organizace pro osvobození Palestiny, v angličtině známá jako Palestine Liberalization Organization.

66 Záznam z návštěrvy izraelského chargé d'affaires u zástupce ved. 9. t. o. dr. Žabokrtského dne 13. 6. 66, čj. 024767. AMZV Praha, TO-T, Izrael, 1965-1969, kart. 1.

67 Více viz Curtis, Michael - Gitelson, Susan: Israel in the Third World. New Jersey 1976.

68 Levy Eškol (1895-1969), původním jménem Levy Školnik, byl izraelský politik a jeden z vůdců sionistického hnutí. Zastával řadu vedoucích politických pozic, v letech 1963-1969 byl izraelským premiérem. 
které z problémů, jejichž kořeny lze hledat v událostech souvisejících s šestidenní válkou, ovlivňují regionální politiku do současnosti.

Již v květnu 1967, kdy bylo zřetelné stále stoupající napětí mezi Izraelem a jeho arabskými sousedy, vydalo Československo oficiální prohlášení, ve kterém Izrael varovalo před rozpoutáním vojenského konfliktu. Československo od počátku vyjadřovalo plnou podporu arabské straně, přičemž jako jediného viníka zodpovědného za eskalaci napětí v oblasti označilo Izrael a imperialistické intriky. ${ }^{70}$ Dne 7. června předal izraelský chargé d'affaires v Praze Jehuda Nassie zástupcům československého ministerstva zahraničních věcí dopis izraelského premiéra Levyho Eškola určený československému prezidentovi a předsedovi vlády. V tomto dopise Eškol objasňoval důvody Izraele pro zahájení vojenské operace, které vysvětloval jako nutnou sebeobranu před plánovaným útokem Egypta, a zároveň žádal o mezinárodní podporu. ${ }^{71}$

Není překvapivé, že vzhledem k dlouhodobě nepříliš dobrým vzájemným vztahům Československo prezentované izraelské důvody pro započetí šestidenní války okamžitě odmítlo a Izrael odsoudilo jako agresora. Již 10. června 1967 Československo zaslalo izraelské vládě telegram in claris, ve kterém ji informovalo o přerušení vzájemných diplomatických styků, uzavření vyslanectví v Tel Avivu a okamžitém odjezdu československého chargé d'affaires Jiřího Skoumala s celým personálem ze země. Stejný postup zvolily i všechny ostatní evropské socialistické země, s výjimkou Rumunska. ${ }^{72}$

\section{Závěr}

Československo-izraelské diplomatické vztahy se ve sledovaném období let 1948-1967 vyznačovaly značnou dynamikou. Zásadní rozdíly se objevují především při porovnání vývoje do konce 40. let 20. století, který byl charakteristický nadstandardním přátelstvím, a zbytkem sledovaného období ukončeného přerušením oficiálních diplomatických styků v roce 1967 - již před tímto definitivním zlomem však lze označit vzájemné vztahy jako chladné. Značnou roli zde sehrály důležité mezinárodně-politické události odehrávající se v reáliích probíhající studené války jako například Suezská krize (1956) a šestidenní válka (1967), které postoj Československa k Izraeli významně formovaly.

Přesto lze konstatovat, že navzdory těmto změnám v přístupu k Izraeli zůstávaly určitou konstantou dva základní determinanty. Jako první determinant lze označit sounáležitost principů československé zahraniční politiky s postoji Sovětského svazu. Druhým výrazným determinantem byla snaha šíriit principy socialismu a podporovat ty osobnosti/politické subjekty, které měly k této ideologii vstřícný postoj - především se jednalo o podporu zahraničním komunistům, avšak ne zcela výhradně. Po událostech šestidenní války se Československo zaměřilo na jednoznačnou podporu všech proti-izraelsky

70 Návrh prohlášeni MZV ČSSR k situaci na Blizkém a Středním východě, čj. 111454, 25. 5. 1967, s. 2-3. NA Praha, A ÚV KSČ 1945-1989, KTAN-II, kart. 109.

71 Izrael - poselství ministerského předsedy, čj. 024225, 8. 6. 1967, s. 2. AMZV Praha, TO-T, Izrael, 1965-1969, kart. 1.

72 Izrael-Instrukce pro ZÚ Tel Aviv, čj. 024818, 12. 6. 1967. AMZV Praha, TO-T, Izrael, 1965-1969, kart. 1. 
naladěných států a hnutí v regionu Blízkého východu. Období vzájemného antagonismu mezi Československem a Izraelem přetrvalo až do roku 1989, kdy v návaznosti na změnu vládnoucího režimu v Československu a přehodnocení zahraničně-politických priorit státu došlo 9. února 1990 k opětovanému navázání vzájemných vztahů.

Případová studie československo-izraelských politických vztahů v letech 1948-1967 poukazuje na řadu dílčích či definitivních rozpadů, rozkolů a konců. Ve střednědobé perspektivě došlo k zpřetrhání přátelských vazeb mezi Československem a Izraelem, nicméně se nejednalo se o definitivní konec, ale o dočasný rozkol způsobený realitou studené války. Tento vývoj dokazuje mimo jiné skutečnost, že k opětovnému navázání vzájemných diplomatických vztahů obou zemí došlo bezprostředně po pádu komunistického režimu v Československu a v současnosti je Česká republika považována za jednoho z nejbližších spojenců Izraele v Evropské unii.

\section{Czechoslovak Diplomacy and the Causes of Breaking the Friendly Relations with Israel}

In May 1948, the independent State of Israel was declared in the former British Mandate for Palestine. The declaration was expected by the international community as Jewish nationalists, known as Zionists, had been attempting to get their own independent state since the end of $19^{\text {th }}$ century. While the right of self-estimation of a nation was widely recognized after World War II, there were only few countries that were willing to support actively the new-born Jewish state in expected war against the alliance of Arab states.

Since late 1947, Czechoslovak leaders had a couple of meetings with the Zionists that resulted into a more intense cooperation including the military training of Jewish volunteers as well as the arms supplies to Hagana, the future army of Israel. Concurrently Czechoslovakia provided a diplomatic support to the Zionist project on the level of United Nations, and officially recognized Israel only a few days after the declaration of independence. This pro-Israeli attitude was not affected by communist coup that came in Czechoslovakia in February 1948 as the collaboration was to continue in next months. It is important to highlight that the reasons for this cooperation were quite pragmatic as Czechoslovakia received payment for her military aid. However, it is also fair to say that in late 1940s the eastern bloc was still expanding and there were some hopes that Israel might have become one of their allies in the Middle East.

Within next few years the mutual relations of the two countries made a significant shift and moved to the open hostility. One of the milestone was definitely the trial with Rudolf Slansky and his co-workers in early 1950s. Since that moment, the anti-Semitism and anti-Israeli attitude were the permanent elements of official Czechoslovak foreign policy culminating in breaking of the diplomatic relations in 1967 in response to the events of Six Days war. 